
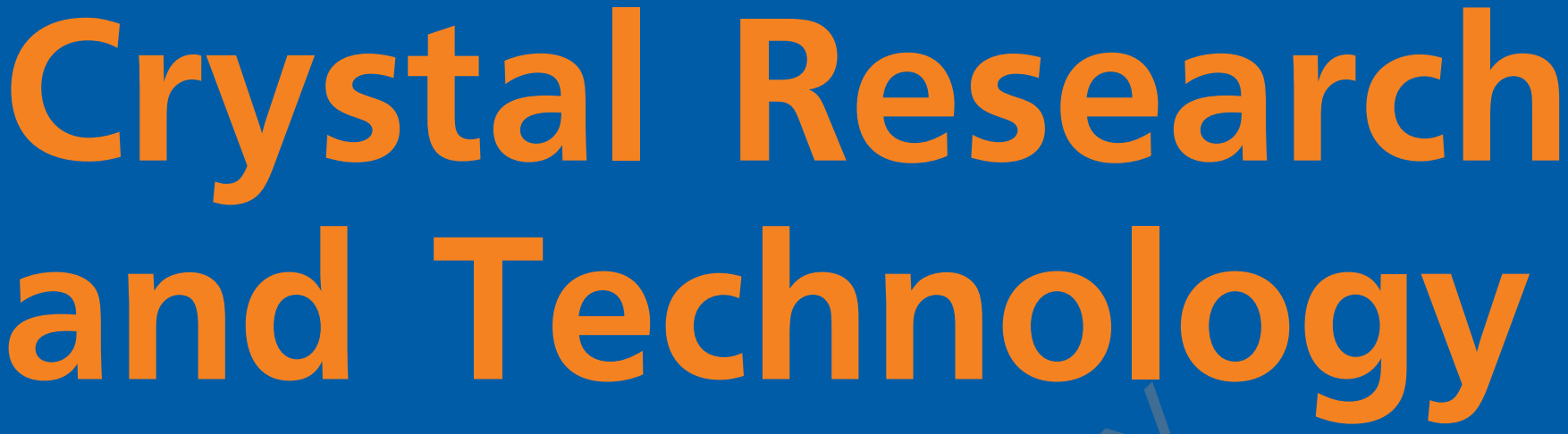

$$
\text { Journal of Experimental and Industrial Crystallography }
$$

Zeitschrift für experimentelle und technische Kristallographie

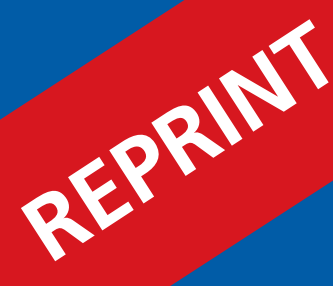




\title{
$T(x)$ phase diagram of the $\mathrm{CuSbS}_{2}-\mathrm{CuInS}_{2}$ system and solubility limit of Sb in $\mathrm{CuInS}_{2}$
}

\author{
B. V. Korzun*1, A. N. Gavrilenko ${ }^{2}$, A. A. Fadzeyeva ${ }^{1}$, O. V. Ignatenko ${ }^{1}$, I. I. Maroz ${ }^{1}$, \\ V. R. Sobol ${ }^{3}$, M. Rusu ${ }^{4}$, R. Klenk ${ }^{4}$, C. Merschjann ${ }^{4}$, Th. Schedel-Niedrig ${ }^{4}$, \\ and M. Ch. Lux-Steiner ${ }^{4}$
}

${ }^{1}$ State Scientific and Production Association "Scientific-Practical Materials Research Centre of the National Academy of Sciences of Belarus", P. Brovki 19, Minsk 220072, Belarus

${ }^{2}$ Kazan State Power University, Krasnoselskaya 51, Kazan 420066, Russia

${ }^{3}$ Belarus State Pedagogical University, Sovetskaya 6, Minsk 220050, Belarus

${ }^{4}$ Helmholtz Zentrum Berlin für Materialen und Energie, Hahn-Meitner Platz 1, 14109 Berlin, Germany

Received 24 July 2013, revised 24 July 2013, accepted 5 August 2013

Published online 26 August 2013

Key words $\mathrm{CuInS}_{2}, \mathrm{CuSbS}_{2}, \mathrm{~T}(\mathrm{x})$ phase diagram, solubility.

The starting ternary compounds $\mathrm{CuInS}_{2}$ and $\mathrm{CuSbS}_{2}$ and alloys of the $\mathrm{CuSbS}_{2}-\mathrm{CuInS}_{2}$ system with the molar fractions of $\mathrm{CuInS}_{2}(x)$ equal to $0.05,0.15,0.25,0.375,0.50,0.625,0.75,0.85$, and 0.95 were prepared and the phase relations in this system were investigated by X-ray powder diffraction, optical microscopy, scanning electron microscopy, and differential thermal analysis. It was shown that the $T-x$ phase diagram of the $\mathrm{CuInS}_{2}-\mathrm{CuSbS}_{2}$ system has a eutectic character with the eutectic temperature of $807 \mathrm{~K}$. The alloys of the $\mathrm{CuSbS}_{2}-\mathrm{CuInS}_{2}$ system with the molar fraction of $\mathrm{CuInS}_{2}$ in the range from 0.038 to 0.941 at room temperature are two-phased, and the limits of solubility are 0.059 molar fractions for $\mathrm{CuSbS}_{2}$ in $\mathrm{CuInS}_{2}$ and 0.038 molar fractions for $\mathrm{CuInS}_{2}$ in $\mathrm{CuSbS}_{2}$.

(C) 2013 WILEY-VCH Verlag GmbH \& Co. KGaA, Weinheim

\section{Introduction}

One of the most promising materials of the I-III-VI 2 group semiconductors is copper indium disulfide $\left(\mathrm{CuInS} \mathrm{S}_{2}\right)$. Initially studied as an electroluminescent material [1], $\mathrm{CuInS}_{2}$ then received significant attention as a solar cell material. The thin-film absorber preparation by coevaporation of the elements on Mo-coated glass substrates leading to a solar cell with $11.4 \%$ efficiency was described [2] and pilot production of the large-area $\mathrm{CuInS}_{2}$-based cells has been developed [3]. The overviews of the current state of scientific understanding and technological development of solar cells based on $\mathrm{CuInS}_{2}$ are presented in [4,5]. It was shown that in order to adjust the physical properties of $\mathrm{CuInS}_{2}$, it is necessary to optimize the technology of doping of this material. Chemical elements of the V-th group As, $\mathrm{Sb}, \mathrm{Bi}$ can be used as such doping elements. The diffusion of $\mathrm{Sb}$ into $\mathrm{CuInS}_{2}$ films has been examined by XPS, SIMS, and electrical measurements [6]. The results suggest that $\mathrm{Sb}$ acts as a compensating donor and can be used to drive the junction away from the heterointerface. It was also found that p-type $\mathrm{CuInS}_{2}$ crystals could be grown by the hot-press method in the range 673-973 K for $1 \mathrm{~h}$ under pressures of 10-100 MPa from $\mathrm{Cu}_{2} \mathrm{~S}, \mathrm{In}_{2} \mathrm{~S}_{3}$, and $\mathrm{Sb}$ powders [7]. It was suggested that the $\mathrm{Sb}$ atoms in the $\mathrm{S}$ site might enhance the p-type conductivity. To determine the limits of solid solubility of $\mathrm{Sb}$ in the $\mathrm{CuInS}_{2}$ ternary compound, it is necessary to study the phase relations in the $\mathrm{CuInS}_{2}-\mathrm{CuSbS}_{2}$ system.

The special feature of this system is that it is formed by two compounds which have analogs among minerals - roquesite $\left(\mathrm{CuInS}_{2}\right)$ and chalcostibite $\left(\mathrm{CuSbS}_{2}\right)$. CuInS 2 is studied actively and it was shown from quenching experiments followed by $\mathrm{X}$-ray analysis that its region of existence is very small and in fact is limited to $0<\mathrm{x}<0.05$ in $\mathrm{Cu}_{1-x} \mathrm{In}_{1+x / 3} \mathrm{~S}_{2}$ [8], or situated in the range composition 50-52 mol.\% of $\operatorname{In}_{2} \mathrm{~S}_{3}$ in the $\mathrm{Cu}_{2} \mathrm{~S}-\mathrm{In}_{2} \mathrm{~S}_{3}$ system [9]. The $T-x$ phase diagram of the $\mathrm{Cu}_{2} \mathrm{~S}-\mathrm{In}_{2} \mathrm{~S}_{3}$ pseudobinary system has been determined by differential thermal analysis and $\mathrm{X}$-ray diffraction $[9,10]$. It appears that $\mathrm{CuInS}_{2}$ exists in three modifications, (i) up to $1253 \mathrm{~K}$

*Corresponding author: e-mail: korzun @ physics.by 
in the chalcopyrite structure, (ii) between 1253 and $1318 \mathrm{~K}$ in the zincblende structure, (iii) and above $1318 \mathrm{~K}$ up to the melting point at $1363 \mathrm{~K}$, in a still unknown structure, which tentatively is assumed to be wurtzite [9]. Study of the phase diagrams of the $\mathrm{Cu}_{2} \mathrm{~S}-\mathrm{In}_{2} \mathrm{~S}_{3}$ and $\mathrm{CuS}-\mathrm{InS}$ pseudobinary systems showed a homogeneity region for $\mathrm{CuInS}_{2}$ at room temperature ranging from $2 \mathrm{~mol} \%$ in the $\mathrm{In}_{2} \mathrm{~S}_{3}$ direction to $1.5 \mathrm{~mol} \%$ in the CuS direction [10].

Knowledge of $\mathrm{CuSbS}_{2}$ is rather scarce and contradictory. $\mathrm{CuSbS}_{2}$ is reported to crystallize in the space group Pnam with 6.016, 3.796, and $14.49 \AA$ for the lattice constants $a, b$ and $c$, respectively [11]. Investigations of the $\mathrm{Cu}_{2} \mathrm{~S}_{-} \mathrm{Sb}_{2} \mathrm{~S}_{3}$ pseudobinary system showed that there is only one ternary compound with the chemical composition corresponding to $\mathrm{CuSbS}_{2}$ in this system [12,13]. It melts congruently with the melting point of 825 [12], 819 [14] or $808 \mathrm{~K}$ [15]. The heat of melting is 19.4 [14] or $8.00 \mathrm{kcal} / \mathrm{mol} \mathrm{[15].}$

The aim of the present paper is to study the phase relations in the $\mathrm{CuSbS}_{2}-\mathrm{CuInS}_{2}$ system by X-ray powder diffraction (XRPD), optical microscopy, scanning electron microscopy (SEM), and differential thermal analysis (DTA). Furthermore, it will be of interest to determine the limit of solubility of $\mathrm{Sb}$ in $\mathrm{CuInS}_{2}$.

\section{Experimental}

The initial elements for the preparation of the $\mathrm{CuSbS}_{2}$ and $\mathrm{CuInS}_{2}$ ternary compounds and their alloys were 99.9998\% copper, $99.9997 \%$ indium, $99.999 \%$ antimony, and $99.9999 \%$ sulfur. The starting ternary compounds and nine alloys of the $\mathrm{CuInS}_{2}-\mathrm{CuSbS}_{2}$ system with the molar fractions of CuInS 2 (x) equal to 0.05, 0.15, 0.25, $0.375,0.50,0.625,0.75,0.85$, and 0.95 were prepared in evacuated and closed quartz ampoules by reaction of the elements at elevated temperatures. To obtain samples by melting, the mixtures of the chemical elements were heated up to $1393 \mathrm{~K}$, exceeding the melting point of $\mathrm{CuInS}_{2}$ by $30 \mathrm{~K}$, and maintained at this temperature for 2 hours. Then, the samples were cooled down to room temperature at a rate of 3-5 K/min. To homogenize the product, the subsequent annealing was carried out at $683 \mathrm{~K}$ for 550 hours.

The phase relations in the $\mathrm{CuSbS}_{2}-\mathrm{CuInS}_{2}$ system were investigated by means of X-ray powder diffraction ( $\mathrm{Cu} \mathrm{K}$ $_{\alpha}$-radiation, $1.5406 \AA$ ), optical microscopy (microscope MIM 7), scanning electron microscopy (electron microscope Jeol, equipped with an energy-dispersive X-ray detector, EDX), and differential thermal analysis (laboratory apparatus).

The DTA measurements were performed using special carriers within a high-temperature steel clamp. The temperatures of the structural phase transitions were determined using Pt/90\% Pt-10\%Rh thermocouples with heating rates being 2-3 K/min (accuracy of $\pm 2 \mathrm{~K}$ ). Reproducible results were obtained by placing powder samples of $1 \mathrm{~g}$ in evacuated $\left(1.3 \cdot 10^{-2} \mathrm{~Pa}\right)$ quartz capsules using $\mathrm{Al}_{2} \mathrm{O}_{3}$ as a reference material. The temperature calibration of the apparatus was achieved by recording solid-state phase transitions and melting of $\mathrm{K}_{2} \mathrm{SO}_{4}(858$ and $1342 \mathrm{~K}), \mathrm{NaCl}(1074 \mathrm{~K})$, and $\mathrm{Na}_{2} \mathrm{SO}_{4}(1157 \mathrm{~K})$.

\section{Results and discussion}

The XRPD data show that most of the prepared alloys of the $\mathrm{CuSbS}_{2}-\mathrm{CuInS}_{2}$ system consist of two phases (figure 1). In figure 1 the Bragg peaks of the phase with the chalcopyrite structure are denoted by symbol * and the Bragg peaks of the phase with the chalcostibite structure are denoted by symbol $\circ$. $\mathrm{CuInS}_{2}$ crystallizes in the tetragonal structure with the lattice constants 5.523 and $11.13 \AA$ for $a$ and $c$, respectively. $\mathrm{CuSbS}_{2}$ crystallizes in the orthorhombic structure with the lattice constants $6.015,3.792$, and $14.464 \AA$ for $a, b$ and $c$, respectively. From XRPD results it can be concluded that the solubility of $\mathrm{CuInS}_{2}$ in $\mathrm{CuSbS}_{2}$ and $\mathrm{CuSbS}_{2}$ in $\mathrm{CuInS}_{2}$ does not exceed 0.05 molar fractions of the ternary compound.

The microstructure studies using optical microscope (figure $2 \mathrm{a}, \mathrm{b}$ ) and scanning electron microscope (figure 2c) confirmed the absence of the formation of complete solid solutions in the $\mathrm{CuSbS}_{2}-\mathrm{CuInS}_{2}$ system. Crystals based on the compound with a higher melting point $\left(\mathrm{CuInS}_{2}\right)$, which crystallize first, grow in liquids until they coalesce. The primary crystals with the chalcopyrite structure based on the $\mathrm{CuInS}_{2}$ ternary compound crystallize in a regular form. The regularity of crystallographic forms is detected as dendrites in figure $2 \mathrm{a}, \mathrm{b}$ (grains of black colour). When the content of $\mathrm{CuInS}_{2}$ increases these primary crystals are completely growing together and a phase based on $\mathrm{CuSbS}_{2}$ is detected as irregular inclusions (figure 2c, black colour).

The results of the determination of the chemical composition of these two phases are presented in table 1. They indicate that the alloys of the $\mathrm{CuSbS}_{2}-\mathrm{CuInS}_{2}$ system with the molar fraction of $\mathrm{CuInS}_{2}$ in the range from 


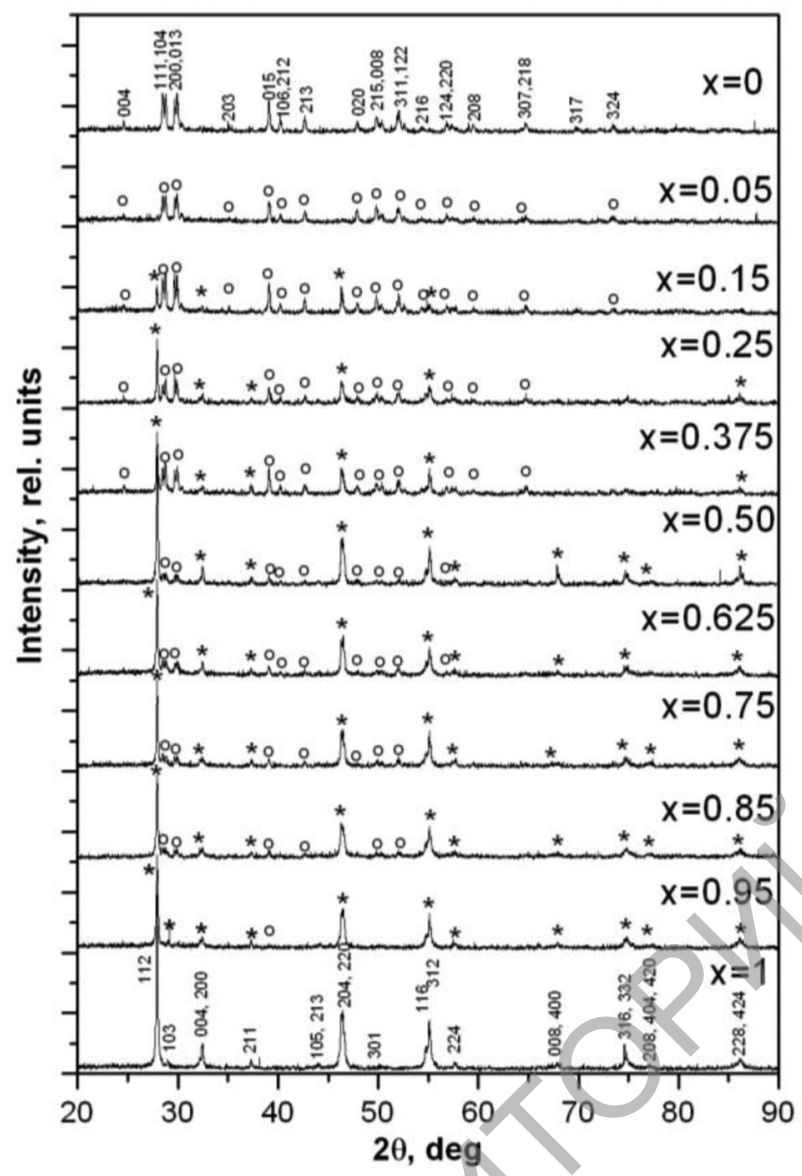

Fig. 1 XRPD patterns at room temperature for $\mathrm{CuInS}_{2}(\mathrm{x}=1), \mathrm{CuSbS}_{2}(\mathrm{x}=0)$, and alloys of the $\mathrm{CuSbS}_{2}-$ $\mathrm{CuInS}_{2}$ system. The denotation of XRPD patterns for alloys corresponds to their initial composition, expressed in molar fractions of $\mathrm{CuInS}_{2}$.

Table 1 Chemical composition of different alloys of the $\mathrm{CuSbS}_{2}-\mathrm{CuInS}_{2}$ system, determined from EDX measurements.

\begin{tabular}{|c|c|c|}
\hline Initial composition & he chalcopyrite structure & Phase with the chalcostibite structure \\
\hline $\begin{array}{l}\mathrm{CuSbS}_{2} \\
\mathrm{CuIn}_{0.15} \mathrm{Sb}_{0.85} \mathrm{~S}_{2} \\
\mathrm{CuIn}_{0.50} \mathrm{Sb}_{0.50} \mathrm{~S}_{2} \\
\mathrm{CuIn}_{0.85} \mathrm{Sb}_{0.15} \mathrm{~S}_{2}\end{array}$ & $\begin{array}{l}\mathrm{CuIn}_{0.888} \mathrm{Sb}_{0.056} \mathrm{~S}_{1.894} \\
\mathrm{CuIn}_{0.928} \mathrm{Sb}_{0.058} \mathrm{~S}_{1.979} \\
\mathrm{CuIn}_{0.980} \mathrm{Sb}_{0.064} \mathrm{~S}_{1.995}\end{array}$ & $\begin{array}{l}\mathrm{CuSb}_{0.928} \mathrm{~S}_{1.764} \\
\mathrm{CuIn}_{0.038} \mathrm{Sb}_{0.983} \mathrm{~S}_{1.919} \\
\mathrm{CuIn}_{0.046} \mathrm{Sb}_{0.944} \mathrm{~S}_{1.934} \\
\mathrm{CuIn}_{0.031} \mathrm{Sb}_{0.960} \mathrm{~S}_{1.834}\end{array}$ \\
\hline
\end{tabular}

0.038 to 0.941 at room temperature consist of two phases. Thus, the limits of solubility are 0.059 molar fractions for $\mathrm{CuSbS}_{2}$ in $\mathrm{CuInS}_{2}$ and 0.038 molar fractions for $\mathrm{CuInS}_{2}$ in $\mathrm{CuSbS}_{2}$.

Figure 3 shows the DTA heating and cooling curves of the alloys of the $\mathrm{CuInS}_{2}-\mathrm{CuSbS}_{2}$ system. The behavior of $\mathrm{CuSbS}_{2}$ during cooling shows that for this compound a supercooling is characteristic and crystallization occurs at the eutectic temperature of the $\mathrm{Cu}_{2} \mathrm{~S}-\mathrm{Sb}_{2} \mathrm{~S}_{3}$ system at $750 \mathrm{~K}$. It proves that the homogeneous composition does not correspond to the stoichiometric composition of $\mathrm{CuSbS}_{2}$, as was previously argued [12-14], and shifts towards the $\mathrm{Sb}_{2} \mathrm{~S}_{3}$ binary compound. As seen on the other thermograms, the thermal peak denoted as 1 is also caused by this fact, namely, the displacement of the homogeneous composition from the stoichiometric composition $\mathrm{CuSbS}_{2}$ and the beginning of melting (or end of crystallization) at the eutectic temperature in the $\mathrm{Cu}_{2} \mathrm{~S}-\mathrm{Sb}_{2} \mathrm{~S}_{3}$ system at $750 \mathrm{~K}$.

The thermal peak denoted as 2 and occurring at $807 \mathrm{~K}$ corresponds to the eutectic horizontal in the $\mathrm{CuSbS}_{2}-$ $\mathrm{CuInS}_{2}$ system as it arises at the temperature lower than the melting point of the low-melted compound in this 

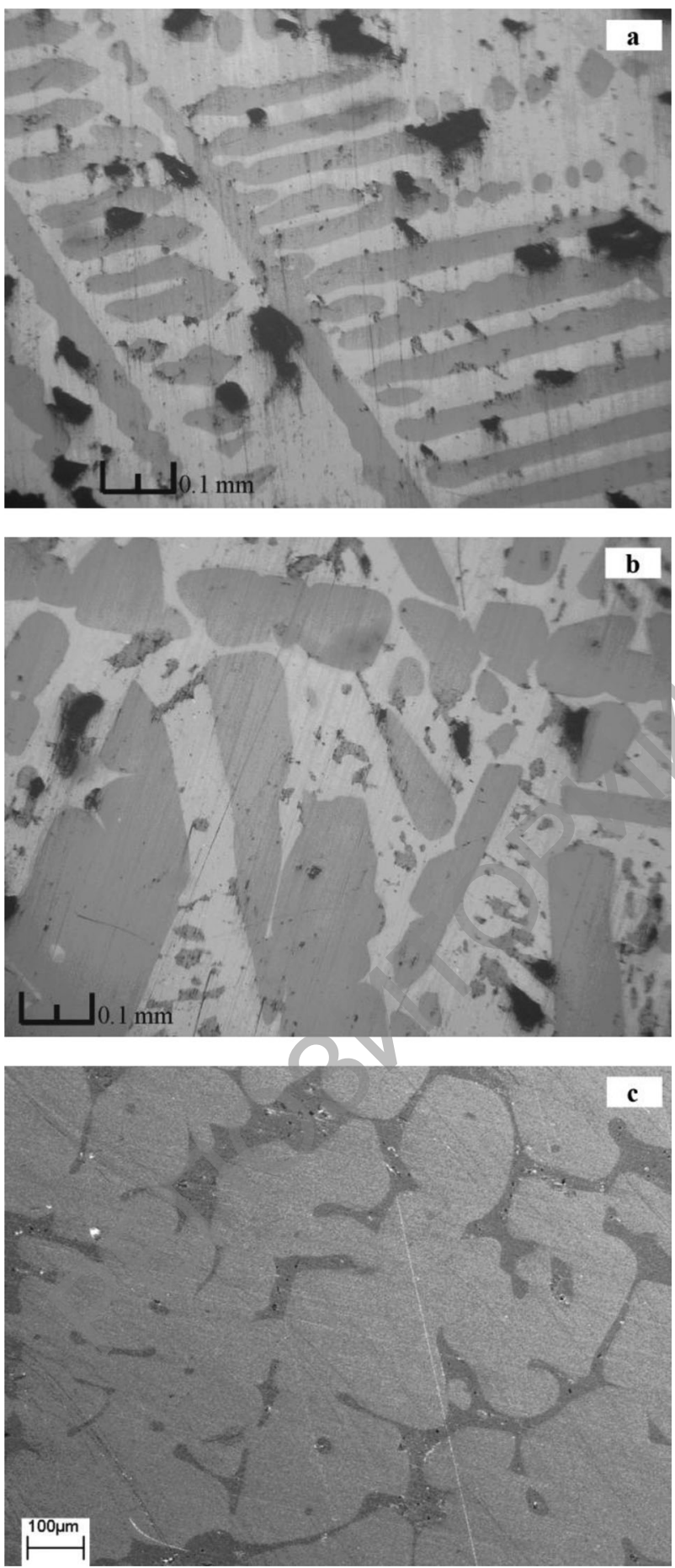

Fig. 2 Microstructure of alloys of the $\mathrm{CuSbS}_{2}-\mathrm{CuInS}_{2}$ system with $\mathrm{x}=0.15$ (a), 0.50 (b), and 0.85 (c) molar fractions of $\mathrm{CuInS}_{2}$.

system $\mathrm{CuSbS}_{2}(823 \mathrm{~K})$. The composition of the eutectics is not determined but can not exceed 0.05 molar fractions of $\mathrm{CuInS}_{2}$. Since melting of alloys of this system takes place over a temperature range of $400 \mathrm{~K}$ for the $\mathrm{CuInS}_{2}$-rich alloys, the end of melting is displayed by an additional endothermic peak denoted on the thermograms as 3 . 

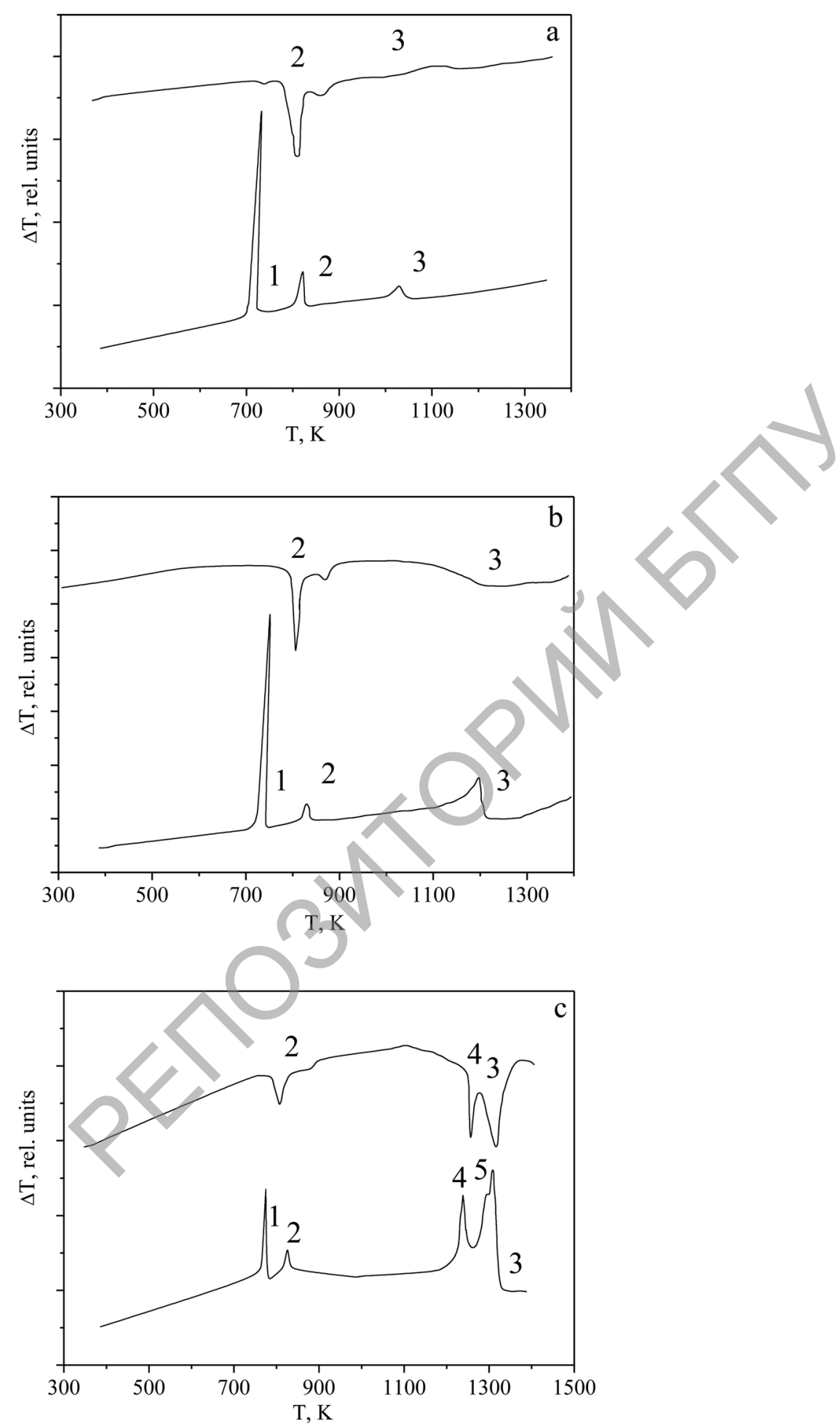

Fig. 3 DTA heating (top) and cooling (bottom) curves of alloys of the $\mathrm{CuSbS}_{2}-\mathrm{CuInS}_{2}$ system with $\mathrm{x}=0.15$ (a), 0.50 (b), and 0.85 (c) molar fractions of $\mathrm{CuInS}_{2}$. 


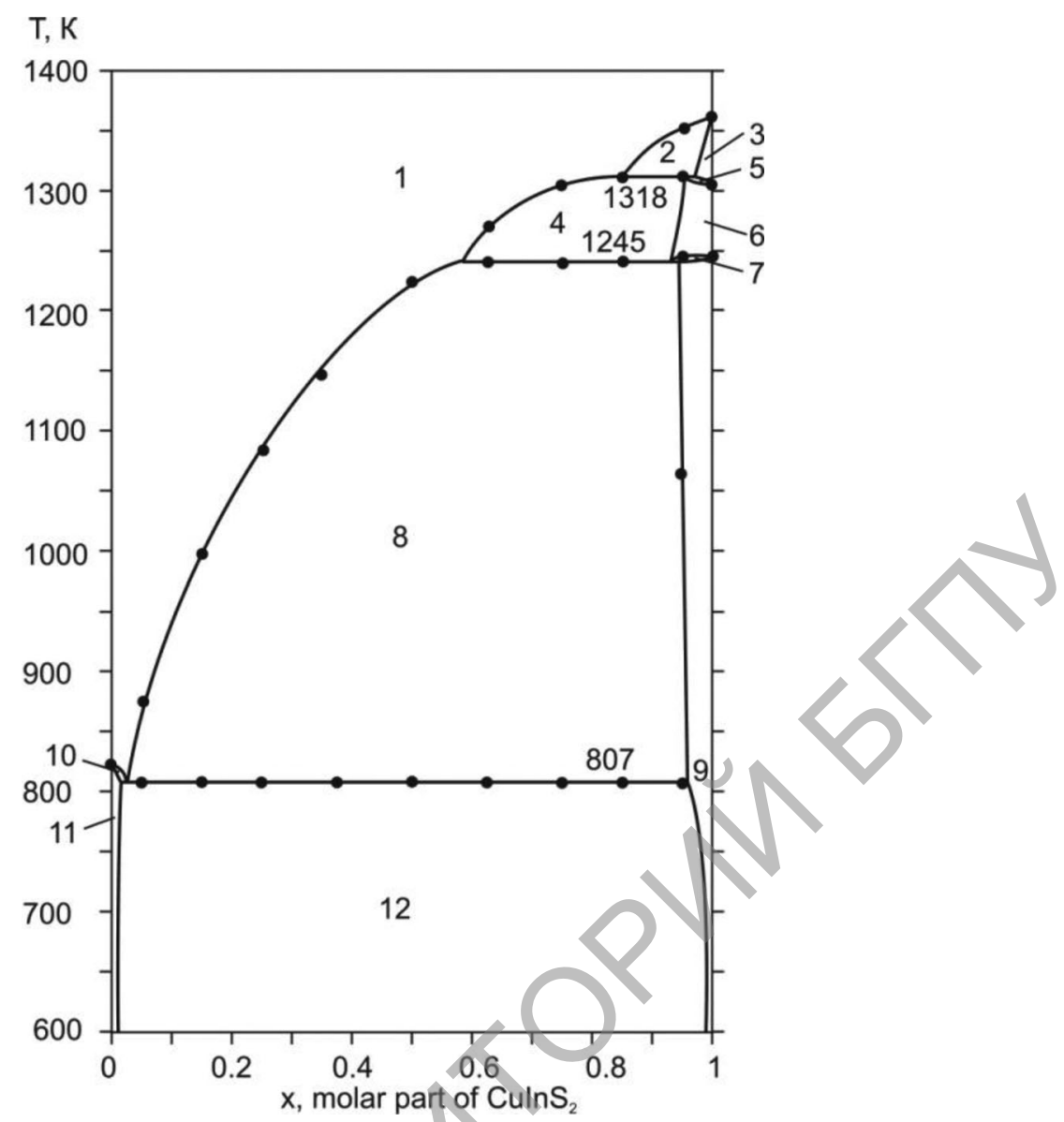

Fig. 4 T-x phase diagram of the $\mathrm{CuSbS}_{2}-\mathrm{CuInS}_{2}$ system. Numbers denote the phase fields: 1: L, 2: $\mathrm{L}+\gamma, 3$ : $\gamma, 4: \mathrm{L}+\beta, 5: \gamma+\beta, 6: \beta, 7: \beta+\alpha, 8: \mathrm{L}+\alpha, 9: \alpha, 10: \mathrm{L}+\delta, 11: \delta, 12: \alpha+\delta$. Here, $\mathrm{L}$ is liquid, $\gamma$ is a presumably phase with the wurtzite structure, $\beta$ is a phase with the sphalerite structure, $\alpha$ is a phase with the chalcopyrite structure, and $\delta$ is a phase with the chalcostibite structure.

The existence of $\mathrm{CuInS}_{2}$ in three polymorphic modifications leads to further complication of interactions in this system. In addition to the thermal effect of melting, at high temperatures the thermograms of the alloys based on the $\mathrm{CuInS}_{2}$ ternary compound have two thermal peaks caused by the polymorphous transformations (figure $3 \mathrm{c}$ ). The thermal peak 4 is caused by a structural phase transition from the tetragonal chalcopyrite structure to the cubic sphalerite structure (zinc blend structure).

The nature of the second polymorphic transformation is presumably a phase transition from the sphalerite structure to the wurtzite structure (SG $P 6_{3} \mathrm{mc}$ ). This second phase transition for the alloy with the initial composition $\mathrm{CuIn}_{0,85} \mathrm{Sb}_{0,15} \mathrm{~S}_{2}$ (figure 3c) is shown only on the cooling curve and denoted as 5 . The T-x phase diagram of the $\mathrm{CuSbS}_{2}-\mathrm{CuInS}_{2}$ system has the eutectic character, where the temperature of the eutectic is $807 \mathrm{~K}$ (figure 4). Taking into account the results of XRPD, the microstructure investigations, and DTA, it can be concluded that the alloys of the $\mathrm{CuSbS}_{2}-\mathrm{CuInS}_{2}$ system with the molar fraction of $\mathrm{CuInS}_{2}$ in the range from 0.038 to 0.941 at room temperature consist of two phases, and the limits of the solubility are 0.059 molar fractions for $\mathrm{CuSbS}_{2}$ in $\mathrm{CuInS}_{2}$ and 0.038 molar fractions for $\mathrm{CuInS}_{2}$ in $\mathrm{CuSbS}_{2}$.

The transitions from the chalcopyrite structure to the sphalerite structure and from the chalcopyrite structure to the presumably wurtzite structure for the $\mathrm{CuInS}_{2}$ ternary compound are not connected with the existence of the two-phase region and are direct transitions. For the alloys of the $\mathrm{CuSbS}_{2}-\mathrm{CuInS}_{2}$ system these transitions occur through the temperature interval of coexistence of two phases, with the chalcopyrite structure and the sphalerite structure (field 7 of T-x phase diagram, figure 4) and with the sphalerite structure and presumably the wurtzite structure (field 5). The analogous behaviour, namely, coexistence of two phases (chalcopyrite and sphalerite), has 
been also discovered for the $\mathrm{CuInS}_{2 x} \mathrm{Se}_{2(1-x)}$ solid solutions in the whole range of compositions excluding pure phases $\mathrm{CuInS}_{2}$ and $\mathrm{CuInSe}_{2}$ [16]. The line of polymorphic transformation from the chalcopyrite structure to the sphalerite structure is situated at $1245 \mathrm{~K}$ and the line of polymorphic transformation from the sphalerite structure to the presumably wurtzite structure is situated at $1318 \mathrm{~K}$ (figure 4).

It is also noteworthy that the covalent atomic radii for In and Sb are similar and equivalent to $0.142(5)$ and $0.139(5) \mathrm{nm}$, respectively [17]. Ionic radii of $\mathrm{In}$ and $\mathrm{Sb}$ are also similar -0.080 and $0.076 \mathrm{~nm}$ for $\mathrm{In}^{+3} \mathrm{and} \mathrm{Sb}^{+3}$ ions, respectively [18]. This contributes to the formation of complete series of solid solutions in this system formed by the two ternary compounds with covalent (or covalent-ionic) chemical bond. The electronegativities of In and Sb differ and have values 1.78 and 2.05, respectively [19]. Taking into account that the electronegativity of $\mathrm{S}$ atoms is 2.58 [19], the electronegativity difference between two atoms is 0.77 and 0.59 for the $\mathrm{In}-\mathrm{S}$ and $\mathrm{Sb}-\mathrm{S}$ bond, respectively. Thus, with the replacement of In by Sb, there is a decrease of the difference in electronegativity between two atoms forming chemical bonds (In and S or Sb and S). In general, with a decrease of the electronegativity difference between two atoms, the more polar bond is the one formed between the atoms, where the atom with the lower electronegativity is at the positive end of the dipole. Covalent bond In $-\mathrm{S}$, in comparison to the covalent bond $\mathrm{Sb}-\mathrm{S}$, is more ionic. As a result, the starting compounds $\mathrm{CuInS}_{2}$ and $\mathrm{CuSbS}_{2}$ crystallize in different crystal structures. The crystal structure of $\mathrm{CuInS}_{2}$ is unstable for the alloys with the In $\mathrm{Sb}$ substitution and these alloys consist of two phases. This is also valid for the $\mathrm{Sb}$ - In substitution, when the crystal structure of $\mathrm{CuSbS}_{2}$ is becoming unstable and the alloys also become two-phased.

\section{Conclusions}

The $\mathrm{CuSbS}_{2}$ and $\mathrm{CuInS}_{2}$ ternary compounds and alloys of the $\mathrm{CuSbS}_{2}-\mathrm{CuInS}_{2}$ system with the molar fractions of $\mathrm{CuInS}_{2}(x)$ equal to $0.05,0.15,0.25,0.375,0.50,0.625,0.75,0.85$, and 0.95 were prepared. The phase relations in this system were investigated using X-ray powder diffraction, differential thermal analysis, optical microscopy, and scanning electron microscopy, equipped with an energy-dispersive X-ray detector. It was established that the $T-x$ phase diagram of the $\mathrm{CuSbS}_{2}-\mathrm{CuInS}_{2}$ system has a eutectic character with the eutectic temperature of $807 \mathrm{~K}$, the composition of the eutectics is not determined but can not exceed 0.05 molar fractions of $\mathrm{CuInS}_{2}$. The alloys of the $\mathrm{CuSbS}_{2}-\mathrm{CuInS}_{2}$ system with the molar fractions of $\mathrm{CuInS}_{2}$ in the range from 0.038 to 0.941 at room temperature consist of the two phases. The limits of solubility are 0.059 molar fractions for $\mathrm{CuSbS}_{2}$ in $\mathrm{CuInS}_{2}$ and 0.038 molar fractions for $\mathrm{CuInS}_{2}$ in $\mathrm{CuSbS}_{2}$.

Acknowledgements It is a pleasure to thank Prof. Dr. S. Fiechter for helpful discussion and Ms. C. Kelch for fruitful help with the SEM studies (both Helmholtz Zentrum Berlin für Materialen und Energie, Berlin, Germany). The partial financial support from the Belarusian Republican Foundation for Fundamental Research (grant No. Ф06-166) is greatly appreciated.

\section{References}

[1] P. M. Bridenbaugh and P. Migliorato, Appl. Phys. Lett. 26, 459 (1975).

[2] K. Siemer, J. Klaer, I. Luck, J. Bruns, R. Klenk, and D. Bräunig, Sol. Energ. Mat. Sol. Cells 67, 159 (2001).

[3] N. Meyer, A. Meeder, and D. Schmid, Thin Solid Films 515, 5979 (2007).

[4] R. Klenk, J. Klaer, R. Scheer, M. Ch. Lux-Steiner, I. Luck, N. Meyer, and U. Ruhle, Thin Solid Films 480-481, 509 (2005).

[5] R. Klenk, J. Klaer, C. Köble, R. Mainz, S. Merdes, H. Rodriguez-Alvarez, R. Scheer, and H.W. Schock, Sol. Energ. Mat. Sol. Cells 95, 1441 (2011).

[6] I. Hengel, R. Klenk, E. Garcia Villora, and M.-Ch. Lux-Steiner, $2^{\text {nd }}$ World Conference and Exhibition on Photovoltaic Solar Energy Conversion (6-10 July, 1998, Vienna, Austria) 546 (1998).

[7] H. Komaki, K. Yoshino, Y. Akaki, M. Yoneta, and T. Ikari, Phys. Stat. Sol. (c) 0, 759 (2003).

[8] A. W. Verheijen, L. J. Giling, and J. Bloem, Mater. Res. Bull. 14, 237 (1979).

[9] J. J. M. Binsma, L. J. Giling, and J. Bloem, J. Cryst. Growth 50, 429 (1980).

[10] S. Fiechter, Y. Tomm, M. Kanis, R. Scheer, and W. Kanetek, Phys. St. Sol. (b) 245, 1761 (2008).

[11] M. F. Razmara, C. M. B. Henderson, R. A. D. Pattrick, A. M. T. Bell, and J. M. Charnock, Mineral. Mag. 61, 79 (1979).

[12] R. A. Kuliev, A. N. Krestovnikov, and V. M. Glazov, Zhurnal fizicheskoi chimii XLIII, 3063 (1969).

[13] R. A. Kuliev, A. N. Krestovnikov, and V. M. Glazov, Neorganicheskie materialy 5, 2233 (1969).

[14] V. M. Glazov, R. A. Kuliev, and A. N. Krestovnikov, Neorganicheskie materialy 6, 2194 (1970). 
[15] R. Blachnik and B. Gather, Z. Naturforschung 27B, 1417 (1972).

[16] I. V. Bodnar and B. V. Korzun, Mater. Res. Bull. 18, 519 (1983).

[17] B. Cordero, V. Gomez, A. E. Platero-Prats, M. Reves, J. Echeverria, E. Cremades, F. Barragan, and S. Alvarez, Dalton Trans. 2832 (2008).

[18] L. Pauling, The Nature of the Chemical Bond, Cornell University Press, Ithaca 1980.

[19] R. D. Shannon, Acta Cryst. A32, 751 (1976). 